\title{
PENGARUH STRATEGI BAURAN PEMASARAN TERHADAP HARGA PADA HOME INDUSTRI JENANG "MIRAH" PONOROGO
}

\author{
Prasetiyani Ika Saputri \\ Pendidikan Ekonomi FKIP UNIVERSITAS PGRI MADIUN \\ saputri_cicipao@yahoo.com
}

\begin{abstract}
Of this study was to determine the marketing mix strategy in Home Industry Jenang "MIRAH" in Ponorogo, to determine the pricing of products in Home Industry Jenang "MIRAH" in Ponorogo. Marketing Mix Strategy is one factor in the price. The samples in this study using sampling techniques saturated as many as 39 people. Sampling using techniques sampling. Results of simple linear regression $Y=43,477+0,558 X$, meaning that if the price increase of $1 \%$, then marketing mix strategy will increase by 0,558 if other factors held constant. It is obtained from $t_{\text {count }}$ on marketing mix strategy variable $(X)$ is 9,440 with 0,000 signifkansi level. Because 9,440 $>1,68488$ and $0.000<0.05$, which expressed their rejection of Ho means the marketing mix strategy effect on price. It can be concluded that $t_{\text {hitung }}>t_{\text {table }}$ ie, greater than $t$ table of a significance level of $0.000 t$ less than 0.05 then the research hypothesis reject Ho and accept Ha. While the results of $R^{2}$ of 0.670 , indicating that $67 \%$ strategy marketing mix variables influenced the price, while the remaining $33 \%$ is influenced by other factors not examined. Conclusion there is the effect of strategy marketing mix on price satisfaction in Home Industry Jenang "MIRAH" in Ponorogo.
\end{abstract}

Keywords: Marketing Mix Strategy, Pricing

\begin{abstract}
Abstrak
Penelitian ini bertujuan untuk mengetahui strategi bauran pemasaran di Home Industri Jenang "MIRAH", serta penetapan harga produk di Home Industri Jenang "MIRAH" Ponorogo serta untuk mengetahui pengaruh strategi bauran pemasaran terhadap hargapada Home Industri Jenang "MIRAH" Ponorogo. Sampel penelitian ini 39 orang.Pengambilan sampel menggunakan sampling jenuh. Populasi penelitian ini karyawan Jenang "MIRAH". Hasil uji regresi linier sederhana adalah $\mathrm{Y}=43,477+0,558 \mathrm{X}$, artinya variabel strategi bauran pemasaran meningkat $1 \%$ harga akan meningkat sebesar 0,558 , faktor lain dianggap tetap. Diperoleh dari nilai $t_{\text {hitung }}$ pada variabel strategi bauran pemasaran (X) adalah 0,9440 dengan tingkat signifikansi 0,000 karena $0,9440 \geq 1,68488$ dan $0,000 \leq 0,05$ yang menyatakan penolakan Ho artinya strategi bauran pemasaran berpengaruh pada harga. Dapat disimpulkan $t_{\text {hitung }} \geq t_{\text {tabel }}$ yaitu lebih besar dari $t$ tabel dari signifikansi $t$ sebesar 0,000 lebih kecil dari 0,05 hipotesis penelitian menolak Ho dan menerima Ha. Hasil $\mathrm{R}^{2}$ sebesar 0,670 , menunjukkan sebesar $67 \%$ variabel strategi bauran pemasaran dipengaruhi harga, sedangkan sisanya 33\% dipengaruhi oleh faktor lain yang tidak diteliti. Kesimpulannya ada pengaruh antara strategi bauran pemasaran terhadap harga pada Home Industri Jenang "MIRAH" di Kabupaten Ponorogo.
\end{abstract}

Kata Kunci: Strategi Bauran Pemasaran, Harga 


\section{PENDAHULUAN}

Perdagangan sekarang ini menunjukkan semakin ketatnya persaingan diantara para produsen dalam memasarkan produk dan jasa untuk menarik konsumen yang akan membeli dan menggunakan produk dan jasanya. Dalam perkembangan pemasaran dan perdagangan, produsen harus mempunyai ide-ide kreatif dan inovasi-inovasi baru agar produk yang dihasilkan tidak selalu monoton di mata konsumen sehingga dalam pemasaran produk dan jasanya akan mengalami kemajuan dan peningkatan yang signifikan secara terus menerus.

Dalam studi penelitian manajemen (I Kadek Suarjana, dkk: 2014:02) bauran pemasaran merupakan salah satu konsep kunci dalam teori pemasaran modern yang sangat penting dan selalu menjadi pertimbangan konsumen dalam membeli sebuah produk.

Harga (price) adalah sejumlah uang yang ditagihkan atas suatu produk atau jasa, dan jumlah dari nilai yang ditukarkan para pelanggan untuk memperoleh manfaat dari memiliki atau menggunakan barang dan jasa.Harga merupakan satu-satunya elemen dalam bauran pemasaran yang menghasilkan pendapatan dan paling fleksibel yang dapat berubah dengan cepat.( Philip Kotler dan Gary Armstrong, 2008: 345).

Maka, strategi bauran pemasaran diperlukan oleh produsen untuk memasarkan dan menetapkan harga produk, sedangkan untuk konsumen bauran pemasaran digunakan untuk memilih-milih harga yang cocok untuk mereka, sesuai dengan produk, tempat, dan promosi yang ditawarkan kepada mereka. Selain memperhatikan faktor internal perusahaan dalam menetapkan harga strategi bauran pemasaran juga diperlukan untuk mendukung pangsa pasar yang dapat menambah laba, serta pemasukan bagi perusahaan. Karena strategi bauran pemasaran terdapat didalam strategi pemasaran yang menjadi tolak ukur suatu perusahaan dalam menjalankan suatu bisnis atau penjualan produknya.

Home Industri Jenang "MIRAH" adalah industri yang memproduksi makanan. Dalam setiap produksi home industri ini mengutamakan kualitas jadi dapat dipastikan dalam memproduksi jenang selalu baru dan langsung dipasarkan, agar pelanggan tidak bosan home industri ini juga membuat berbagai macam varian jenang sebagai pilihan.

Untuk menjalankan kegiatan produksinya karyawan dibentuk dan dibagi dari memilih bahan untuk membuat jenang sampai pemasarannya kepada konsumen dan pelanggan. Sehingga dalam Home Industri Jenang "MIRAH" karyawan dituntut untuk memiliki keterampilan di bidangnya masingmasing agar produktivitas dan kualitasnya terjamin.

\section{METODE PENELITIAN}

Penelitian ini dilakukan di Home Industry Jenang "MIRAH" Ponorogo. Penelitian ini termasuk ke dalam penelitian kuantitatif dimana data yang digunakan berbentuk angka. Yang menjadi variabel bebas (X) adalah strategi bauran pemasaran dan yang menjadi variabel terikat (Y) adalah harga.

Populasi dalam penelitian ini adalah karyawan yang jumlahnya 39 orang. Sampel dalam penelitian ini sebanyak 39 karyawan. Teknik pengambilan sampel yang digunakan yaitu Nonprobability sampling dengan menggunakan teknik sampling jenuh.

Dalam pengambilan sampel menggunakan kuesioner berupa pernyataan dengan jumlah 50 pernyataan dengan 25 pernyataan strategi bauran pemasaran dan 25 pernyataan harga. Observasi menggunakan observasi pertisipasi yang digunakan untuk menghimpun data penelitian melalui pengamatan secara langsung sehingga peneliti ikut serta 
mengamati pengaruh strategi bauran pemasaran terhadapharga. Dokumentasi digunakan untuk mendapatkan data yang obyektif dari responden. Data dokumentasi berupa hasil foto selama proses penelitian.

Indikator strategi bauran pemasaran menurut Sofjan Assauri (2011:198) adalah sebagai berikut:1) Strategi Produk2) Strategi Harga 3) Strategi Tempat atau Distribusi 4) Strategi Promosi. Sedangkan Indikator harga menurut Fandy Tjiptono (2008: 154) adalah sebagai berikut: 1) Tujuan Pemasaran Perusahaan 2) Strategi Bauran Pemasaran 3) Biaya 4) Organisasi 5) Sifat Pasar dan Permintaan 6) Persaingan 7) Unsur-Unsur Eksternal.

Sebelum melakukan penelitian instrument dalam hal yaitu kuesioner harus diuji terlebih dahulu keabsahannya menggunakan uji validitas yang berguna untuk mengetahui apakah ada pernyataan pada kuesioner yang tidak valid/relevan. Kemudian diuji reliabilitasnya menggunakan Alfa Cronbach.

Untuk uji hipotesis menggunakan teknik analisis regresi linear sederhana menggunakan koefisien determinasi dan uji t. Koefisien determinasi digunakan untuk menguji pengaruh antara variable satu dengan yang lain. Variabel yang dimaksud adalah variable independen yaitu strategi bauran pemasaran $(\mathrm{X})$ dan variable dependen yaitu harga (Y).Sedangkan uji t digunakan untuk mengetahui apakah variable independen (X) secara individu mempunyai pengaruh yang signifikan terhadap variable dependen (Y).

\section{HASIL DAN PEMBAHASAN}

GambaranUmum Home Industri Jenang "MIRAH" Ponorogo

Jenang "Mirah" Ponorogo berada di kabupaten Ponorogo, berdiri pada tahun 1955 dan dipimpin oleh Bapak Handoko sebagai pemilik sekaligus pengelola di Jl. Kh Moh. Mansyur, Josari, Jetis, Kabupaten Ponorogo. Setiap harinya Home Industri Jenang "Mirah"
Ponorogo memproduksi jenang dengan varian rasa dan bentuk yang beragam.Produk jenang di Home Industri Jenang "Mirah" Ponorogo sudah memiliki izin dari Dinas Kesehatan Ponorogo.

\section{Variabel Strategi Bauran Pemasaran pada Home Industri Jenang “Mirah" Ponorogo}

Berdasarkan tabel diatas, dapat dideskriptifkan bahwa variabel strategi bauran pemasaran pada Home Industry Jenang "MIRAH" Ponorogo dengan jumlah data $(\mathrm{N})$ sebanyak 39 karyawan memiliki deskriptif data sebagai berikut: strategi bauran pemasaran berada diatas nilai rata-rata sebanyak 26 karyawan atau sebesar $66,6 \%$ sedangkan yang dibawah rata-rata 13karyawan atau sebesar 33,3\%. Maka dapat disimpulkan bahwa Dengan demikian karyawan tidak merasa keberatan dengan strategi bauran pemasaran yang digunakan oleh Home Industri Jenang “Mirah” Ponorogo.

\section{Variabel Harga pada Home Industri Jenang "Mirah" Ponorogo}

Berdasarkan tabel diatas, dapat di deskriptifkan bahwa variabel harga pada karyawan di Home Industry Jenang "MIRAH" Ponorogo dengan jumlah data $(\mathrm{N})$ sebanyak 39karyawan memiliki deskripsi data sebagai berikut : harga berada diatas nilai rata-rata sebanyak 25 karyawan atau sebesar 64,1\% sedangkan yang dibawah rata-rata 14 karyawan atau sebesar 35,8\%. Dari hasil analisis di atas, sebagian besar karyawa cukup puas dengan harga yang di tetapkan di Jenang "Mirah" Ponorogo banyak konsumen yang datang untuk membeli dan pendapatan karyawan pun akan dibayarkan pada waktunya.

\section{Hasil Uji Hipotesis}

\section{Uji Analisis Regresi Liniear Sederhana}

Uji Analisis Regresi Liniear Sederhana diperoleh persamaanY $=43,477+0,558 \mathrm{X}$. Konstanta sama dengan 43,477 , artinya 
apabila variabel strategi bauran pemasaran tetap atau konstant, maka besarnya harga adalah 0,558 .

\section{Koefisien Determinasi (R-Square)}

Dari hasil pengolahan data dengan menggunakan program SPSS versi 16.0 dapat diketahui bahwa koefisien determinasi (R Square) yang diperoleh sebesar 0,670. Yaitu berarti $67 \%$ strategi bauran pemasaran dipengaruhi oleh harga, sedangkan sisanya $33 \%$ harga dipengaruhi oleh variabel variabel lain yang diteliti dalam penelitian ini.

\section{Ujit}

Dari tabel di atas dapat diketahui bahwa nilai $t_{\text {hitung }}$ adalah 9,440 sedangkan $t_{\text {tabel }}$ sebesar 1,68488, di lain pihak nilai $\mathrm{Sig}_{\text {hit }}$ sebesar 0,000 sedangkan $\mathrm{Sig}_{\text {prob }}$ 0,05. Hal ini berarti bahwa nilai $t_{\text {hitung }} \geq t_{\text {tabel }}(9,440 \geq 1,68488)$ atau $\operatorname{Sig}_{\text {hit }} \leq \operatorname{Sig}_{\text {prob }}(0,000 \leq 0,05)$. Atas dasar uji $\mathrm{t}$ tersebut dapat disimpulkan ditolak, artinya ada beda pengaruh antara strategi bauran pemasaran terhadap harga pada Home Industri Jenang “Mirah” Ponorogo.

\section{PENUTUP}

\section{Simpulan}

Berdasarkan hasil analisis data dan pembahasan di atas, maka dapat disimpulkan sebagai berikut:

1. Strategi Bauran Pemasaran pada Home Industri Jenang "Mirah" Ponorogo dilihat dari hasil sebaran angket terhadap 39 karyawan. Dihasilkan nilai rata - rata sebanyak 89,21 sehingga diperoleh nilai yang di atas rata - rata sebanyak 26 karyawan atau sebesar $66,6 \%$ sedangkan yang di bawah rata - rata sebanyak 13 orang atau sebesar $33,3 \%$.

Maka dapat disimpulkan bahwa strategi bauran pemasaran pada Home Industri Jenang "Mirah" Ponorogo berjalan dengan baik meski dengan lokasi yang kurang strategis konsumen dan pelanggan akan tetap membeli jenang karena mutu dan kualitas jenang yang sudah terjamin, pengemasan jenang yang sudah modern, menerima keluhan dari konsumen dengan cepat, dan memberikan potongan harga dalam pembelian yang banyak pada Home Industri Jenang “Mirah” Ponorogo.

2. Harga yang ditetapkan pada produk jenang di Home Industri Jenang "Mirah" Ponorogo dari hasil sebaran angket terhadap 39 karyawan dihasilkan nilai rata - rata sebanyak 90,23 sehingga diperoleh nilai yang berada di atas rata rata sebanyak sebanyak 25 karyawan atau sebesar 64,1 \% sedangkan yang di bawah rata - rata sebanyak 14 karyawan atau sebesar 35,8\%.

Maka dapat disimpulkan bahwa perusahaan sudah menetapkan harga pada setiap produknya dengan irisannya atau dengan setiap kemasannya dari harga yang paling rendah sampai harga yang paling tinggi. Meskipun pada saat harga bahan baku pembuatan jenang mengalami kenaikan, Jenang "Mirah" Ponorogo hanya mengurangi ukuran jenang yang mereka jual tanpa merubah kwalitas jenangnya.

3. Strategi Bauran Pemasaran mempunyai pengaruh terhadap Harga pada Jenang "Mirah" Ponorogo. Terbukti dari hasil analisis melalui:

a. Uji Regresi Linear Sederhana, Dari hasil Uji Regresi Linear Sederhana diperoleh $\mathrm{Y}=43,477+0,558 \mathrm{X}$ yang artinya konstanta sama dengan 43,477 artinya apabila variabel strategi bauran pemasaran tetap atau konstan, maka besarnya harga adalah 0,558 sehingga ada pengaruh yang signifikan antara strategi bauran pemasaran terhadap harga.

b. Koefisien Determinasi yang digunakan untuk mengetahui seberapa besar prosentase strategi bauran pemasaran terhadap harga. Diketahui $\mathrm{R}^{2}$ adalah 
0,670. Artinya strategi bauran pemasaran terhadap harga yaitu $67 \%$ sedangkan sisanya 33\% dipengaruhi oleh faktor lain.

c. Melalui penelitian dengan Uji $\mathrm{T}$ diperoleh nilai 9,440 sedangkan sebesar 1,68488, di lain pihak nilai sebesar 0,000 sedangkan 0,05 . Hal ini berarti bahwa nilai $t_{\text {hitung }} \geq t_{\text {tabel }}(9,440 \geq 1,68488)$ atau $\operatorname{Sig}_{\text {hit }} \leq \operatorname{Sig}_{\text {prob }}(0,000 \leq 0,05)$. Atas dasar uji t tersebut dapat disimpulkan ditolak, artinya ada beda pengaruh antara Strategi Bauran Pemasaran Terhadap Harga.

\section{Saran}

Berdasarkan hasil dan kesimpulan di atas, maka saran yang dapat diberikan adalah sebagai berikut:

1. Bagi Perusahaan (Jenang "Mirah" Ponorogo)

Berdasarkan hasil observasi dan hasil dari angket strategi bauran pemasaran yang sudah disebar diharapkan Home Industri Jenang "Mirah" Ponorogo tetap menjaga kualitas produknya, untuk meningkatkan keinginan konsumen untuk membeli ulang. Serta menggunakan strategi bauran pemasaran yang tepat, mengalami peningkatan dalam penjualan sehingga laba perusahaan akan terus bertambah. Dengan laba yang dihasilkan oleh perusahaan maka gaji dan kesejahteraan karyawannya akan terjamin. Serta meningkatkan kualitas pelayanan dengan baik dan menerima komplain secara serius. Dengan demikian akan terpenuhinya harapan dan keinginan pelanggan dan konsumen.

2. Bagi Pelanggan

Bagi pelanggan yang membeli diharapkan mampu memilih produk yang sesuai dengan harapan, keinginan, dan harga yang terjangkau serta memiliki kualitas yang bermutu sehingga pelanggan puas dan tidak merasa dirugikan dengan produk yang dibeli. Dalam pembelian suatu produk seharusnya konsumen memilih dengan cermat apabila sudah terlanjur membeli barang dengan pengemasan yang rusak atau melihat tanggal pada kemasan makanan itu sudah kadaluarsa maka seharusnya pembeli berhak untuk mengembalikan produk tersebut ke tokonya kembali.

3. Bagi Penelitian selanjutnya

Bagi peneliti selanjutnya sebaiknya mengembangkan penelitian ini dengan menambah atau mencari variabel lain selain strategi bauran pemasaran karena masih banyak lagi faktor yang mempengaruhi harga seperti kwalitas produk, mutu produk, dan biaya produksi.

4. Bagi UNIVERSITAS PGRI MADIUN.

Dengan penelitian ini diharapkan memberikan tambahan pemikiran dalam pengembangan ilmu pengetahuan tentang masalah harga terhadap kepuasan pelanggan. Serta dapat menjadi tambahan referensi perpustakaan.

\section{DAFTAR PUSTAKA}

Assauri, Sofjan. 2011. Manajemen Pemasaran: Dasar, Konsep, dan Strategi. Jakarta. PT Raja Grafindo Persada.

Khotler, Philip, Armstrong, Gary. 2008. Prinsip-Prinsip Pemasaran. Jakarta. Erlangga.

Suarjana, Kadek, I. 2014. Pengaruh Bauran Pemasaran terhadap Keputusan Pembelian di Indomaret Kecamatan Tampaksiring Gianyar. e-Jurnal Bisma Universitas Pendidikan Ganesha Jurusan Manajemen. Volume 2 Tahun 2014. Singaraja. Jurusan Manajemen Universitas Pendidikan Ganesha.

Tjiptono, Fandy. 2008. Strategi Pemasaran. Yogyakarta. C.V.Andi Offset. 